\title{
Between Knowledge, Belief and Desire, Green Utopia and Its Application
}

\section{Hooman Foroughmandaraabi* \& Maryam Khabazi**}

* Science and Research Branch, Islamic Azad University, Tehran, Iran, hoomanforoughmand@yahoo.com ** Science and Research Branch, Islamic Azad University, Tehran, Iran, maryamkhabazi@ymail.com

\begin{abstract}
:
Nowadays despite multifarious prescriptions of sustainable development, there is an approach of sustainable values in any development's agenda. Considering the paradigm shift from the modern idea of growth, which had been considered to be able to compensate any negative effect of growth, to postmodern paradigm of development, which is obsessed about nature conservation, this article has made a model for green utopia. Three different but related factors are forming the utopia: knowledge, beliefs and desire. Human knowledge of the nature (as a complicated system) is forming this Green Future vision, knowledge vividly pictures a dystopia if the world denied following the knowledge, as well. In addition to knowledge, our beliefs play an important role. The last and the most important source of this utopia is human desire, unlike its predecessors it is not perfect. The conclusion of this article is a model for a green or sustainable utopia that is achieved through this study. Debating on different statements applications tries to optimize the utopia.
\end{abstract}

KEYWORDS: utopia, green utopia, ideal sustainable city, postmodern vision of city, knowledge, beliefs, desire 


\section{INTRODUCTION}

Concept of green development is now widely accepted, but in many cases this approach was not effective; This widespread accepted value has a semi-utopian role in seeking for a better life and forming this life. By recognizing the fundamental sources of this ideal city, it would be possible to improve the efficacy of this kind of ideal city and to avoid any confusion. This becomes more important when we consider the global level of sustainable developments, it is meaningless to imagine that some counties become sustainable while other destroying the nature as our knowledge says that the ecosystems around the whole earth are deeply related, somehow the destiny of the world depends on the global pro-environmental actions. In this situation imaginary ideal places should be very close to the nature in the public mind. Green utopia is such a place. How it merged? What are its features? And other questions about it are very important, but the most important query about it is how we can use this concept in the best way? By answering firs questions this article suggests a model to optimize the dealing with the green utopia.

\section{UTOPIA}

Utopia is a sort of place without any negative feature, its etymology goes back to the Plato books, the republic, While Plato innovated this concept, Tomas More coined the word Utopia which means nowhere (combination of $U$ means no and topia means place), this word itself implies that this concept is unachievable and the term refers to an ideal place that is not possible, in fact one of the key features of utopias is that, through history many writers explain their utopias, from Saint-Simon with a communism concept to Bacon with emphasize on unlimited knowledge [13].

There is not a single list of the features of utopias but the majority of them have the same character, in an utopia there is no change because that place is in the best and complete situation and nothing can improve or damage it, otherwise this would be a weakness for that place, an utopia, additionally, is supposed to be very desirable in More's utopia, trees in the utopia nurture prepared foods, in utopias money does grow on trees and other wishes are achieved there, but there are another kind of no place where on the contrary are dark places without these features, Dystopia Many successful books are in this category such the 1984 by George Orwell The subject of these books have been critical views toward communism or capitalism or condemning technology and environmental destroys, generally it seems that the human have been seeking for a better place and its signs are recognizable in many novels, movies poems painting etc. in built environment related fields like urban design of its origin architecture learning utopias has been important because it shows the aim or wishes of people [7] and [13], many books like history of urban form explain these utopias, in renaissance particularly star-shaped cities showed what was the ideal form of city for people at those period of time, in many real cities this plan could be chased, however there are shapeless utopias [16] even in these utopias the relation between wish and action could be the subject of study, some believe that utopian role of making built environment has been with plans from the very first ones[10].

\section{GREEN UTOPIA}

Sustainable, Green or environmentally friendly development and many other words are evolving around some obscure concepts, common aspects of this concept are "developing without destroying the future" or "less consuming, best using". Historically, this point of view toward the nature and development is a result of postmodern thought. While in the modern thought this believe that the human and technology can change the world and any side effect would be fixed by human technology and science; this idea of development ended up in destroying the nature. In the postmodern, thought this general idea toward development shifted to the less egotistical point of view that respect the nature and now, to be exact, the public believe that the human cannot change the nature, but he should conserve it, Green utopia is the result of this thought. In the common belief, nowadays approximately all plans should follow the sustainability principles, the approach of this 
point of view is future without damaging the nature, this green utopia despite the multifarious versions of it now is the propaganda of the postmodern world, we can find it not only in developing plans but in many NGO's ${ }^{1}$ goals. In many movies like the "Fahrenheit 451" and many Hollywoodian movies it is possible to chase this case [3] The Green utopia is still very vague, but like its predecessors in many fields these concepts are in use. Especially, in built-environment-related fields the attention to a better place has been common many philosophers, writers and even politicians have been concerned about utopian aspects of planning or utopian points of view [4] and [16]. Nowadays, in these fields sustainable development is the only accepted way of development [11]. Therefore, a conceptual study of this concept is very important. The Green Utopia is combined from three different concepts: knowledge, belief and desire.

\section{KNOWLEDGE}

Some reports and research during the 80 's showed that the future by that consuming rate of that day would be a catastrophe, at the same time the human knowledge about the earth resources and the capability of the nature to absorb pollutions confirmed that point [11]. So, the human knowledge is supporting the sustainable developments, many research programs at university and institutions are to do so, and many groups think that enhancing the public knowledge would end up in more sustainable behavior. The human knowledge about nature usually frightens the public about the future (a dystopia) but at the same time to encourage people to follow their sustainability principles it pictures a good environment of future, Compact city samples are very well known, or new urbanism picture of good city adapted with the nature is really passionate. While overall vision of sustainable cities is like a mirage it is not achievable, a degree of sustainability is all that can be achieved in some conditions. So, knowledge is one of the most important and significant sources, which updates every time.

\section{BELIEF}

Many texts in the Green literature are full of still-unproved statements, the global warming for one; these statements are results of beliefs (believe as states or habits of mind in which trust or confidence is placed in some persons or things). Some studies reveal the role of belief in the way that human interpret his/her surrounded world. Green attitude toward development could be an example of this; human kind do not think that the nature is able to absorb all pollutions, or we are not sure that we will find ways in which all pollutions become sources for further growth. Our common image of a better place is deeply based on our belief about the world in which we live and our interpretation of it [9].

\section{DESIRE}

After the new worldwide care about the nature, the Green development has been the subject of many advertisements including activities from local groups to the UN, these advertisements inherently were to show what they were advertising would be very desirable, but this desirable situation at least compared to the previous ones was far less desirable [8]. While any wish came to be a reality in ordinary Utopias in the Green utopia all things are very natural, healthy and realistic, these thing are not as desirable as the imaginary Utopias, we all prefer a place where we can go with our personal car, without any tax, easy to find a parking lot by a car that does not damage the nature at all but what the green development approach brings for us is a sort of public transportation which could be desirable but it is not the best choice every time. We can say the green utopia is a sort of eutopia, the utopia that is accompanied by euphoria. The green utopia also reminds us all threats that could happen if we do not fallow its principle, this brings a sort of fear from the black future or a dystopia which could be recognized in many movies and novels.

The green Utopia however has another special feature which is deeply related to the human nostalgia. In fact, many pictures that sustainable development and its origin (postmodernism) provide come from past, many thinkers mentioned this reference to the period before the industrialization/modernization in postmodern

\footnotetext{
1 Non-Governmental Organization
} 
movements [6]. Despite the fact that in many versions of the Green city high level of technology is in use, compact city for instance, the image of being close to the nature without pollution inevitably reminds the image of pre-modern settlements and current local villages. In this aspect the green utopia is imaginable and desirable for people while some Utopias are very out of this world. In different aspects the green utopia is controversial this is not strange in the postmodern context where paradoxical trends melt to each other; attempts to make this ideal place realistic at the same time makes it less desirable, that is why conceptually there are many disparities between the current utopia and the previous ones.

\section{MODEL}

Each of three mentioned parts (knowledge, belief and desire) has their own role in ameliorating and confining the concept of Green utopia, while knowledge encourage people to follow sustainability it puts some borders for desire. Knowledge, on the other hand, can be powerful in refuting beliefs after renaissance people usually do not believe in unscientific, in more exact words, do not believe in beliefs scientifically refuted statements. The third interaction of these three concepts is between desire and belief; historical studies of utopias emphasize on this aspect when they point that utopists write utopias according to their belief, just like the Republic of Plato where the writer explained how this utopia came out from more transcendental concepts like justice, Plato saw the justice in a caste system for a society when [14] More and many left-handed thinkers found justice in equality of all rights and benefits [13], in this interaction it is controversial to find which made which, whether belief in equality made it desirable or desire for equality made the belief. To make it easier, we can consider this interaction in the way that desire and belief make each other, and in the case of Green utopia belief in limitation of the earth recourses and desire for a nature friendly place, which is nostalgic, are forming the utopia. Figure I show the model in which Green utopias has been made.

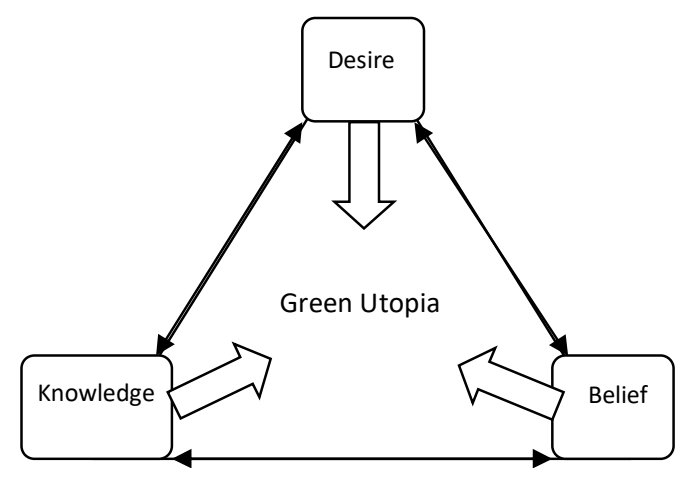

Figure 1 conceptual

The value and essence of these disparate concepts that make the utopia are different, in other word Green utopia is an amalgamate of different essences, considering the different versions of this utopia it is very possible that some statements of this utopia became the subject of disuse, for example, in urban development activities if the experts try to embody the public desire for Green utopia it will face problems because this desire is not that much result of knowledge therefore there is not good principles to achieve it. This mean for each statement in the concept of green utopia the source of the statement should be clear to some extend from three concepts (knowledge, desire and belief) therefore dealing with each part should be different. Table I provides some information about these disparities, It should be mentioned here that like many conceptual divisions the borders and definitions is not absolute, some statements could be considers as desire while others think it is based on belief for example, in many cases the statement could be a combination of two concepts but the ability to recognize the source of it and placing it at the best situation would improve 
the approach making in many plans from social activities to public place planes. Table I tries to prove such example, generally statements which are based on desire are not that much realistic and in putting these statements in planning hierarchy it could be an aim, very high level that is not that much practical, while any one can have his especial utopia of desire the society usually get informed from ones that are made but thinkers, artists and other dreamers the process of making these parts come from reversing bad situations around the thinker, so this part could easily change. Contrary to the first part knowledge-based aspects of the green utopia is developed methodologically by scientists and it could be very practical, many researches try to achieve realistic objectives though this statements are at the low place of planning hierarchy. Belief based statements are very fundamental and can affect other part of people life, ideological views of a better place are on the border of desire and belief and could be made by both the society as a common belief or by individuals, usually plans emphasize on common beliefs and its values become normative goals in the hierarchy of planning.

\begin{tabular}{|c|c|c|c|c|c|}
\hline & Who make it? & How is it made? & Is it realistic? & Is it practical? & Example \\
\hline Desire & $\begin{array}{l}\text { Thinkers/ } \\
\text { dreamers }\end{array}$ & $\begin{array}{l}\text { By reversing all } \\
\text { bad situations and } \\
\text { experiences }\end{array}$ & no & As an aim & $\begin{array}{l}\text { Bucolic character, } \\
\text { Metropolitan amenities }\end{array}$ \\
\hline Knowledge & Scientists & $\begin{array}{l}\text { By researches, } \\
\text { examining } \\
\text { hypothesis }\end{array}$ & yes & As a tool & Minimized pollution \\
\hline Belief & $\begin{array}{l}\text { Society and } \\
\text { individuals }\end{array}$ & $\begin{array}{l}\text { By cultural } \\
\text { traditional } \\
\text { concepts }\end{array}$ & partly & As a goal & $\begin{array}{l}\text { Pollution threats the } \\
\text { future }\end{array}$ \\
\hline
\end{tabular}

Table 1

\section{CONCLUSION}

Human kind is used to having utopia through history, in some cases utopias played a positive role in history, many achievements were results of utopia, the Futurists in the last century explained their utopia of technology and many people after them formed that, we can conclude that we are now living in embodied form of utopias of our predecessors while all plans were followed a sort of good place in their mind and like anything else when it comes to reality it is not as passionate as it is in mind! Human kind at the worldwide developments now have the approach of sustainable development, many international organizations and NGOs are following this goal, despite the fact that there are many versions of this Green utopia some aspects are the same between all, to enhance the usage of green utopia this articles tried to show that statements from different sources should be dealt with in different ways otherwise this utopia possible will not be effective in practice and misconceptions will reduce the effectiveness of many plans. 


\section{REFERENCES}

[1] Asil, Hojatollah"ARMANSHAHR DAR ANDISHE IRANI"(Utopias in Iranian Thought), Ney publication, Tehran Iran, IN PERSIAN, 2002.

[2] Berman, Marshal. All that is solid melts into air: the experience of modernity," Simon and Schuster, New York 1982.

[3] Brereton, Pat, "Hollywood Utopia Ecology in Contemporary American Cinema," Intellect Books, UK, 2005.

[4] Choay Françoise, "Urbanisme, utopies et réalités [Mass Market Paperback]," Françoise Choay Points (Seuil), 1979.

[5] Cuthbert, Alexander R., "The form of cities, political economy and Urban design. Oxford, Blackwell, 2006.

[6] Ellin, Nan., "Postmodern Urbanism," Revised edition. New York: Princeton architectural press, 1999.

[7] James Morris, james, "History of urban form: before the industrial revolutions," Longman Scientific \& Technical,1994.

[8] Luisa Passerini, “'Utopia' and Desire," sage publications 2002.

[9] Lynch, Kevin, "Good City Form," Cambridge MA, MIT Press, 1981.

[10] Madanipour, Ali, "Design of Urban Space: An Inquiry into a Socio-spatial Process," John Wiley. 1996,

[11] Moughtin, Cliff and others, "Urban design Green dimensions," Elsevier, 2003.

[12] Rothstein, Edward and others, "Visions of utopia," Oxford, 2003.

[13] Rouvillois, Frédéric, "L’Utopie (textes choisis et présentés)," Flammarion, Paris, 1998.

[14] Santas, Gerasimos, "Understanding Plato’s Republic,” Wiley-Blackwell, 2010.

[15] Solinís ,Germán, "Utopia, the Origins and Invention of Western Urban Design," sage publications, 2006.

[16] Tafuri, Manfredo," Architecture and utopia design and capitalist development," translated from Italian by Barbara Luigia La Penta, MIT press, 1976. 